\title{
PENGARUH PEMBELAJARAN KEWIRAUSAHAAN TERHADAP KETERAMPILAN DAN MINAT WIRAUSAHA PADA SISWA
}

\author{
Danang Prio Utomo \\ Universitas Hamzanwadi \\ Danang_irenk@yahoo.com
}

\begin{abstract}
This study aims to (1) To determine the effect of Learning Entrepreneurship Against Skills And Interests Entrepreneurial Students (2) To determine whether there Effect of Learning Entrepreneurship Against Skills And Interests Entrepreneurial Students (3) To know the effect of Entrepreneurship Learning Skills And Interests of Entrepreneurial Students. This research was ex-post facto. The research object is a class XI student with the number of samples taken as many as 20 people by random sampling technique. Data collection techniques used were questionnaires, observation, documentation. Data analysis technique used is the prerequisite test, statistical tests, and test hypotheses with a simple analysis and ujit t. From the T test results can be seen from the One-sample test, namely: testing of entrepreneurial learning variable $(X)$ on entrepreneurial skills, from the calculation of $t 34.33>2,086$ or sig $(0.00<0.05$. Thus Ha accepted and Ho titolak. for entrepreneurial learning variable $(X)$ of the entrepreneurial Interests (Y2), from the calculation of $t 33.56>2,086$ or sig $(0.00<0.05$. thus Ha Ho accepted and titolak. Based on data analysis concluded that there Effect Against Enterprise Learning Entrepreneurial Skills And Interests.
\end{abstract}

Keywords: Effect Against Entrepreneurship Learning Skills and Interests

\begin{abstract}
Abs Abstrak
Penelitian ini bertujuan untuk (1) Untuk mengetahui Pengaruh Pembelajaran Kewirausahaan Terhadap Keterampilan Dan Minat Wirausaha Pada Siswa (2) Untuk mengetahui apakah ada Pengaruh Pembelajaran Kewirausahaan Terhadap Keterampilan Dan Minat Wirausaha Pada Siswa Pancor (3) Untuk mengetahui Pengaruh Pembelajaran Kewirausahaan Terhadap Keterampilan Dan Minat Wirausaha Pada Siswa. Penelitian ini termasuk penelitian ex-post facto. Obyek penelitian adalah siswa kelas XI dengan jumlah sampel yang diambil sebanyak 20 orang dengan teknik random sampling. Teknik pengumpulan data yang digunakan adalah angket, observasi, dokumentasi. Teknik analisis data yang digunakan yaitu uji prasyarat, uji statistik, dan uji hipotesis dengan analisis sederhana dan ujit t. Dari Hasil uji t dapat dilihat dari One-sample test yaitu: pengujian variabel pembelajaran kewirausahaan (X) terhadap Keterampilan wirausaha, dari hasil perhitungan $t$ hitung 34,33 > 2,086 atau sig $\left(0,00<0,05\right.$. Dengan demikian $H_{a}$ diterima dan Ho titolak. Untuk variabel pembelajaran kewirausahaan (X) terhadap Minat Wirausaha (Y2), dari hasil perhitungan $t$ hitung 33,56 $>2,086$ atau sig $(0,00<0,05$. Dengan demikian $\mathrm{H}_{a}$ diterima dan Ho titolak. Berdasarkan analisis data disimpulkan bahwa terdapat Pengaruh Pembelajaran Kewirausahaan Terhadap Keterampilan Dan Minat Wirausaha Pada Siswa.
\end{abstract}

Kata Kunci: Pengaruh Pembelajaran Kewirausahaan Terhadap Keterampilan dan Minat 


\section{PENDAHULUAN}

Pelaksanaan program pembelajaran pendidikan kejuruan khususnya di Sekolah Menengah Kejuruan (SMK) melalui pembelajaran praktik memegang peranan penting sehingga penguasaan keterampilan kerja pada pembelajaran praktik di SMK dapat teraplikasi secara optimal dalam Pendidikan Sistem Ganda. Pendidikan Sistem Ganda merupakan suatu bentuk penyelenggaraan pendidikan yang memadukan secara sistematik dan sinkron antara program pendidikan disekolah dengan program penguasaan keahlian yang diperoleh melalui bekerja secara langsung didunia kerja atau dunia industri dan terarah untuk mencapai tingkat keahlian profesional tertentu. Pernyataan tersebut menyatakan bahwa pendidikan sistem ganda adalah sistem pendidikan yang proses pembelajaran berlangsung disekolah yang meliputi pendidikan teori dan praktik serta pendidikan langsung.

Sekolah menengah kejuruan (SMK) sebagai salah satu lembaga pendidikan yang mengarah pada pembentukan sikap profesionalisme maka berupaya terus menerus menyusun program-program ataupun kurikulum yang berorientasi pada kemajuan ilmu pengetahuan yang berkarakter dan pada saatnya nanti mampu membekali lulsannya dengan berbagai macam ilmu, berupa pengetahuan teori dan keterampilan dalam praktik yang mampu disesuaikan dengan kebutuhan di lapangan. Selain melakukan keterampilan pendidikan, pemerintah juga saat ini melakukan program standarisasi kompetensi SMK, hal ini dilakukan untuk menstandarkan kualitas lulusannya sesuai dengan standar global yang telah ditetapkan.

SMK NW Pancor merupakan sekolah yang berupaya mengembangkan alumni memiliki keterampilan dan jiwa kewirausahaan. Pendidikan tentang kewirausahaan diberikan kepada seluruh siswa mulai dari semester pertama dengan metode klasikal. Materi yang disampaikan disesuaikan dengan tingkat kelas yang ada. Metode yang dilaksanakan sekolah ini bertujuan untuk meningkatkan minat berwirausaha siswa sejak dini.

Adapun masalah tinggi rendahnya keterampilan dan minat wirausahaa menurut para pakar dipengaruhi oleh dua faktor, yakni faktor yang berasal dari dalam dan luar diri seseorang. Pada penelitian ini, faktor eksternal yang mempengaruhi Keterampilan di fokuskan pada faktor, yakni: (1) faktor pembelajaran berupa proses berlangsungnnya pembelajaran kewirausahaan yang diselenggarakan di sekolah dan faktor eksternal yang mempengaruhi minat wirausaha difokuskan pada faktor eksternal, yakni: (1) faktor lingkungan pendidikan berupa proses pembelajaran kewirausahaan di sekolah dan (2) faktor lingkungan keluarga berupa internalisasi nilai kewirausahaan di keluarga dan latar belakang ekonomi keluarga. Sedangkan faktor internal difokuskan pada pembelajaran kewirausahaan.

Berdasarkan uraian diatas, maka peneliti tertarik untuk melakukan penelitian lebih lanjut dengan judul: "Pengaruh pembelajaran Kewirausahaan Terhadap Keterampilan Dan Minat Wirausaha Pada Siswa kelas XI Jurusan Jasa Boga Di SMK NW Pancor Tahun 2016/2017.

Untuk memperjelas dan mempermudah dalam penelitian maka penulis identifikasikan beberapa masalah, yaitu kurang menariknya penggunaan bahan ajar yang digunakan oleh guru, pemilihan endekatan pembelajaran yang kurang tepat sehingga siswa tidak diberikan kesempatan 
untuk menemukan sendiri dan melakukan observasi secara langsung terhadap suatu objek sebagai sumber pengamatan, menumbuhkan keterampilan dan minat berwirausaha bagi siswa SMK merupakan hal yang penting dan tidak mudah, maka dari itu harus didukung dari beberapa faktor pendukung dari luar dan dari dalam diri siswa.

Dari beberapa permasalahan yang telah diidentifikasi, maka penulis membatasi penelitian pada pengaruh Pembelajaran Kewirausahaan Terhadap Keterampilan dan Minat Wirausaha Pada Siswa kelas XI Jurusan Jasa Boga Di SMK NW Pancor.

Tujuan penelitian ini adalah untuk mengetahui pengaruh pembelajaran kewirausaha terhadap keterampilan dan minat siswa kelas XI jurusan jasa boga SMK NW Pancor Tahun Pembelajaran 2016/2017.

\section{METODE PENELITIAN}

Penelitian ini merupakan jenis penelitian expost facto yaitu peneliti berhubungan dengan variabel yang telah terjadi dan tidak perlu memberikan perlakuan terhadap variabel yang diteliti. Pada penelitian ini variabel bebas dan variabel terikat sudah dinyatakan secara eksplisit (Sugiyono. 2008: 15).

Sesuai dengan tujuannya, yaitu mengungkapkan adanya hubungan antara pembelajaran kewirausahaan terhadap keterampilan dan minat berwirausaha, maka penelitian ini termasuk penelitian korelatif. Penelitian ini menggunakan statistik parametris dengan teknik regresi linier bergandauntuk mencari pengaruh dan membuktikan hipotesis hubungan dua variabel bila data kedua data variabel berbetuk interval atau rasio, dan sumber data dari dua variabel atau lebih tersebut adalah sama.

Penelitian ini menggunakan pendekatan kuantitatif, karena data diwujudkan dalam bentuk angka dan dianalisis berdasarkan analisis statistik guna menunjukkan pengaruh pembelajaran kewirausahaan terhadap keterampilan dan minat berwirausaha.

Populasi adalah wilayah generalisasi yang terdiri dari objek atau subjek yang mempunyai kualitas dan karakteristik tertentu yang ditetapkan oleh peneliti untuk dipelajari dan kemudian ditarik kesimpulannya.

Jadi populasi bukan hanya orang, tetapi juga obyek dan benda-benda alam. Populasi juga bukan sekedar jumlah yang ada pada obyek/subyek yang dipelajari, tetapi meliputi seluruh karakteristik/sifat yang dimiliki oleh subyek atau obyek itu (Sugiyono, 2012: 117).

Populasi dalam penelitian ini kels X, XI, XII Jurusan Jasa Boga Di SMK NW Pancor 2016/2017. Sampel adalah bagian dari jumlah dan karakteristik yang dimiliki oleh populasi tersebut. Untuk menetukan sampel penelitian ini menggunakan teknik Simple Random Sampling. Dikatakan simple (sederhana) karena pengambilan anggota sampel dari populasi dilakukan secara acak tanpa memperhatikan strata yang ada dalam populasi itu. Cara demikian bila anggota populasi dianggap homogen.

Berdasarkan pendapat tersebut, Maka di peroleh kelas XI Jurusan Jasa Boga sebagai sampel yang berjumlah 20 orang. Penelitian ini dilaksanakan di SMK NW Pancor pada siswa kelas XI Jurusan Jasa Boga tahun pelajaran 2016/2017. Setelah terlebih dahulu mengadakan observasi untuk memperoleh informasi. Untuk pemilihan lokasi tersebut karena sesuai dengan tujuan penelitian yang akan peneliti lakukan yaitu untuk mengetahui hubungan pembelajaran kewirausahaan dengan keterampilandan minat 
wirausaha siswa kelas XI Jurusan Jasa Boga Di SMK NW Pancor. Hal ini dikarenakan setelah melakukan observasi kebeberapa sekolah dilihat dari kegiatan kewirausahanya SMK NW Pancor bagus dan banyak kegiatan kewirausahaan sehingga cocok untuk mengetahui hubungan pembelajaran kewirausahaan dengan keterampilan dan minat wirausaha siswa. Penelitian ini dilaksanakan pada bulan November-Desember tahun pembelajaran 2016/2017.

Pembelajaran kewirausahaan adalah usaha yang dilakukan lembaga pendidikan untuk menanamkan pengetahuan, nilai, jiwa dan sikap kewirausahaan kepada peserta didik guna membekali diri menjadi manusia yang mandiri, kreatif dan inovatif. Hal ini juga bertujuan untuk menciptkan wirausaha-wirausaha baru yang handal dan berkarakter dan dapat meningkatkan kesejahteraan masyarakat

Keterampilan wirausaha adalah suatu kemampuan yang dimiliki oleh individu dalam melaksanakan atau menjalankan wirausaha untuk memperoleh jalan menuju kesuksesan.

Minat wirausaha adalah mengindikasikan kesukaan atau ketertarikan seseorang untuk berwirausaha merupakan kunci dari perilaku wirausaha dalam mengkombinasikan kreativitas, inovasi, kerja keras dan keberanian menghadapi resiko untuk memperoleh peluang. Oleh sebab itu wirausaha merupakan potensi pembangunan, baik dalam jumlah maupun dalam mutu wirausaha itu sendiri.

Teknik pengumpulan data yang di gunakan adalah wawancara, angket, observasi dan. Metode yang dipakai dalam penelitian ini adalah.

1. Metode observasi

Metode observasi adalah teknik pengumpulan data yang dilakukan dengan cara pengamatan langsungterhadap obyek yang akan diteliti dengan menggunakan seluruh indera. Dalam arti penelitian observasi dapat dilakukan denganmenggunakan tes, kuesioner, rekaman gambar, rekaman suara (Arikunto, 2006: 156). Pengamatan/observasi yaitu dengan cara penulis melakukan pengamatan langsung untuk mengamati aktivitas yang dilakukan guru, siswa maupun pihak sekolah. Penggunaan teknik observasi yang terpenting adalah mengendalikan pengamatan dan ingatan peneliti, untuk mempermudah pengamatan dalampenelitian digunakan: catatancatatan, alat elektronik berupa kamera, pengamatan, pemusatan pada data-data yang tepat dan menambahbahan presepsi tentang obyek yang diamati.

2. Metode Angket

Menurut Arikunto (2005:100) metode atau tehnik pengumpulan data adalah cara-cara yang dapat digunakan oleh peneliti untuk mengumpulkan data. Ada beberapa tehnik pengumpulan data, yaitu wawancara, angket, observasi dan studi dokumenter. Metode yang dipakai dalam penelitian ini adalah angket/kuesioner. Angket menurut Arikunto (2002: 128) kuesioner adalah sejumlah pertanyaan tertulis yang digunakan untuk memperoleh informasi dari responden dalam arti laporan tentang pribadinya atau hal-hal yang ingin diketahui. Angket/kuesioner yang dipakai dalam penelitian ini adalah angket 
langsung tertutup, karena telah disediakan jawabannya sehingga responden tinggal memilih mana yang sesuai dengan dirinya.

Menurut Arikunto (2010: 194) ada beberapa keuntungan jika menggunakan kuesioner, yaitu:

1. Tidak memerlukan hadirnya peneliti.

2. Dapat dibagikan secara serentak kepada banyak responden.

3. Dapat dijawab oleh responden menurut kecepatannya masing-masing dan menurut waktu senggang responden.

4. Dapat dibuat anonim sehingga responden bebas, jujur dan tidak malu menjawab.

5. Dapat dibuat terstandar sehingga bagi semua responden dapat diberi pertanyaan yang benar-benar sama.

3. Metode Dokumentasi

Metode dokumentasi merupakan metode pengumpulan data dengan menggunakan bahan-bahan informasi yang berupa catatan, transkip, buku, surat kabar atau sumber-sumber lain yang terkait dengan masalahyang hendak diteliti (ArikuntoSuharsimi, 2002: 206). Metode dokumentasi dalam penelitian ini dilakukan untuk mengetahui jumlah dan nama siswa.

Pada prinsipnya meneliti adalah melakukan pengukuran terhadap fenomena sosial maupun alam. Karena pada prinsipnya meneliti adalah melakukan pengukuran, maka harus ada alat ukur yang baik. Alat ukur dalam penelitian biasanya dinamakan instrument penelitian. Jadi instrumen penelitian adalah suatu alat yang digunakan untk mengukur fenomena sosial maupun alam yang diamati. Secara spesifik semua fenomena ini disebut variabel penelitian (Sugiyono, 2013: 102).

Menurut Arikunto (2010: 203) instrument penelitian adalah "alat atau fasilitas yang digunakan oleh peneliti dalam mengumpulkan data agar pekerjaannya lebih mudah dan hasilnya lebih baik, dalam arti lebih cermat, lengkap, dan sistematis sehingga lebih mudah diolah".Sesuai dengan definisi dari instrumen di atas, maka instrumen yang digunakan dalam pengumpulan data untuk penelitian ini adalah: angket atau kuesioner yang ditujukan untuk mengetahui pengaruh pemebelajarankerwirausah terhadap minat berwirausaha pada siswa di SMK NW Pancor. Terdapat tiga angket yaitu instrumen pembelajaran kewirausahaan, keterampilan dan minat berwirausaha. Terdapat tiga angket yaitu instrumen pembelajaran kewirausahaan, keterampilan dan minat berwirausaha.

Instrumen ini dibuat dalam bentuk penilaian model skala Likert karena sekala likert ini berdampingan dengan pertanyaan yang telah direncanakan, dengan tujuan agar responden lebih mudah mengecek maupun memberikan pilihan jawaban yang sesuai dengan pertimabangan mereka (Sukardi, 2003: 146). Untuk lebih lebih jelasnya dapat dilihat pada tabel berikut.

\section{HASIL DAN PEMBAHASAN}

Analisis deskriptif digunakan untuk mengetahui hasil tanggapan responden terhadap pembelajaran kewirausahaan yang mempengaruhi keterampilan dan minat berwirausaha siswa yang digunakan melalui item 
kuesioner yang diajukan dilapangan. Selanjutnya untuk pengolahan distribusi frekuensi tersebut dilakukan dengan mengelompokkan skor total nilai dari jawaban para responden penelitian dan menentukan mean, modus, median dan standar deviasi. Distribusi frekuensi hasil jawaban responden merupakan tingkat kecendrungan pembelajaran kewirausahaan terhadap keterampilan dan minat wirausaha siswa, secara rinci dapat dilihat dalam uraian sebagai berikut ini:

\section{Deskripsi Data Pembelajaran Kewirausahaan (X)}

Dari hasil angket pembelajaran kewirausahaan dengan 10 item pernyataan dan jumlah responden sebanyak 20 orang, maka diperoleh skor tertinggi 42 dan skor terendah sebesar 24. Berdasarakan perhitungan pada lampiran 7 maka diperoleh33 Mi sebesar 33 dan SDi sebesar 3. Agar range ketiap kelas sama maka rumus di modifikasi dengan $x S D i$, dan diperoleh $x=$ 9. Pengkategorian kecenderungan siswa terhadap pembelajaran kewirausahaan adalah sebagai berikut:

Tabel 1.

Pengkategorian Kecenderungan Siswa Terhadap Pembelajaran Kewirausahaan

\begin{tabular}{|c|l|c|c|}
\hline No & \multicolumn{1}{|c|}{ Kategori } & Hitungan & Rentang Skor \\
\hline 1 & Sangat Kurang Baik & $x<24$ & $<24$ \\
\hline 2 & Kurang Baik & $24 \leq x<33$ & $24-32$ \\
\hline 3 & Baik & $33 \leq x<41$ & $33-41$ \\
\hline 4 & Sangat Baik & $42 \leq x$ & $42<$ \\
\hline
\end{tabular}

Sumber:Lampiran 7

Berdasarkan kategori di atas, dapat dibuat tabel identifikasi kategori kecenderungan siswa terhadap pembelajaran kewirausahaan SMK NW Pancor 2016/2017 sebagai berikut:

Tabel 2.

Identifikasi Kategori Kecenderungan Siswa Terhadap Pembelajaran Kewirausahaan

\begin{tabular}{|c|c|c|c|l|}
\hline No & $\begin{array}{c}\text { Rentang } \\
\text { Skor }\end{array}$ & Responden & $\begin{array}{l}\text { Persentas } \\
\mathbf{( \% )}\end{array}$ & \multicolumn{1}{|c|}{ Kategori } \\
\hline 1 & $>23$ & 0 & 0 & Sangat Kurang Baik \\
\hline 2 & $24-32$ & 6 & 30 & Kurang Baik \\
\hline 3 & $33-41$ & 13 & 65 & Baik \\
\hline 4 & 42 & 1 & 5 & Sangat Baik \\
\hline \multicolumn{2}{|r|}{ Total } & 20 & 100 & \\
\hline
\end{tabular}

Sumber: Lampiran 7

Tabel di atas menunjukkan bahwa terdapat 6 responden (30\%) memiliki pandangan tentang pembelajaran kewirausahaan yang kategori kurang baik, 13 responden (65\%) memiliki pandangan pembelajaran kewirausahaan kategori baik, 1 responden (5\%) kategori sangat baik dan $0 \%$ sangat kurang baik. 
Berdasarkan distribusi frekuensi kecendrungan siswa terhadap pembelajaran kewirausahaan, dapat digambarkan ke dalam Pie Chart sebagai berikut:

\section{b. Deskripsi Data Keterampilan Wirausahaa (Y1)}

Data keterampilan wirausaha siswa dengan 10 butir pernyataan dan jumlah responden sebanyak 20 siswa. Maka diperoleh skor tertinggi sebesar 44 dan skor terendah sebesar 21.

- Berdasarkan lampiran 37×maka diperoleh Mi sebesar3×3,832,5 dan SDi sebesar 3,83 maka dari itu, agar range tiap kelas sama maka

rumus dimodifikasi dengan $S D i$, dan diperoleh sebesar 11,49. Pengkategorian keterampilan wirausahaa siswa adalah sebagai berikut:

Tabel 3.

Pengkategorian Keterampilan Wirausaha Siswa

\begin{tabular}{|c|c|c|c|}
\hline No & Kategori & Hitungan & Rentang Skor \\
\hline 1 & $\begin{array}{ll}\text { Sangat } & \text { Kurang } \\
\text { Baik } & \end{array}$ & $x$ & \\
\hline 2 & Kurang Baik & & \\
\hline 3 & Baik & $\underline{x}$ & \\
\hline 4 & $\begin{array}{l}\text { Sangat } \\
\text { Baik }\end{array}$ & $\stackrel{x}{x}_{x}$ & $44<$ \\
\hline
\end{tabular}

Tabel diatas menunjukkan bahwa terdapat 7 responden $352 \%$ ) memiliki pandangan tentang keterampilan wirausahaa siswa dalam kategori kurang baik, 12 responden (60\%) memiliki pandangan tentang keterampilan wirausahaa siswa dalam kategori baik, 5\% dalam kategori sangat baik dan 0\% dalam kategori sangat kurang baik. Berdasarkan distribusi frekuensi kecendrungan keterampilan wirausahaa siswa dapat digambarkan ke dalam Pie Chart sebagai berikut:

\section{Persentase Kategori Y1}

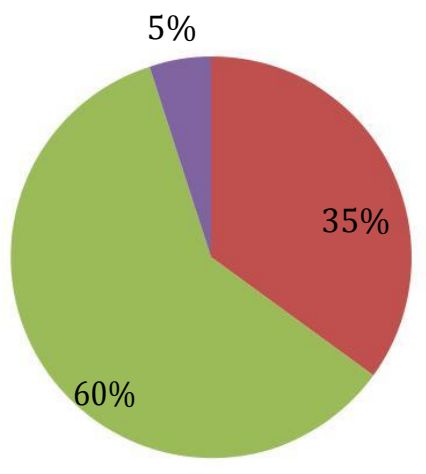

- Sangat Kurang Baik

Kurang Baik

Baik

Sangat Baik 
Gambar 4.2. Pie Chart keterampilan wirausahaa siswa kelas XI di SMK NW Pancor Tahun 2016/2017.

\section{c. Deskripsi Data Minat Wirausaha Siswa (Y2)}

Data Minat wirausahaa siswa dengan 10 butir pernyataan dan jumlah responden sebanyak 20 orang, maka diperoleh skor tertinggi sebesar 43 dan skor terendah sebesar 24 .

Berdasarkan perhitungan3 xpada Lampiran 7 maka3× diperoleh3,16 Mi sebesar 33,5 dan SDi sebesar 3,16. Agar range tiap kelas sama maka rumus dimodifikasi dengan $S D i$, dan diperoleh sebesar 9,48. Pengkategorian minat berwirausaha siswa adalah sebagai berikut:

Tabel 5.

Pengkategorian Minat Berwirausaha Siswa

\begin{tabular}{|c|l|c|c|}
\hline No & \multicolumn{1}{|c|}{ Kategori } & Hitungan & Rentang Skor \\
\hline 1 & $\begin{array}{l}\text { Sangat Kurang } \\
\text { Baik }\end{array}$ & $\mathrm{x}<24$ & $<24$ \\
\hline 2 & Kurang Baik & $24 \leq \mathrm{x}<33,5$ & $24-32,5$ \\
\hline 3 & Baik & $33,5 \leq \mathrm{x}<43$ & $32,5-42$ \\
\hline 4 & Sangat Baik & $43 \leq \mathrm{x}$ & $43<$ \\
\hline
\end{tabular}


Tabel 6.

Identifikasi Pengkategorian Minat Wirausahaa Siswa

\begin{tabular}{|c|c|c|c|l|}
\hline No & $\begin{array}{c}\text { Rentang } \\
\text { Skor }\end{array}$ & Responden & $\begin{array}{c}\text { Persentase } \\
(\mathbf{\% )}\end{array}$ & \multicolumn{1}{|c|}{ Kategori } \\
\hline 1 & $<24$ & 0 & 0 & Sangat Kurang Baik \\
\hline 2 & $24-32,5$ & 6 & 30 & Kurang Baik \\
\hline 3 & $32,5-42$ & 13 & 65 & Baik \\
\hline 4 & $42<$ & 1 & 5 & Sangat Baik \\
\hline \multicolumn{2}{|c|}{ Total } & 20 & 100 & \\
\hline
\end{tabular}

Sumber: Lampiran 7

Tabel di atas menunjukkan bahwa terdapat 6 responden (230\%) memiliki pandangan tentang minat berwirausaha siswa dalam kategori kurang baik, 13 responden (65\%) memiliki pandangan tentang minat berwirausaha siswa dalam kategori baik, 5\% dalam kategori sangat baik dan 0\% dalam kategori sangat kurang baik. Berdasarkan distribusi frekuensi kecenderungan minat berwirausaha siswa dapat digambarkan kedalam Pie Chart sebagai berikut:

\section{PERSENTASE KATEGORI (Y2)}

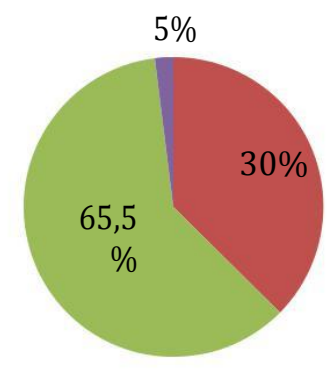

$$
\begin{aligned}
& \text { Sangat Kurang } \\
& \text { Baik } \\
& \text { Kurang Baik } \\
& \text { Baik } \\
& \text { Sangat Baik }
\end{aligned}
$$

\section{Gambar 4.3. Pie Chart Minat Wirausahaa Siswa Kelas XI di SMK NW Pancor Tahun 2016/2017.}

\section{Uji Prasyarat Analisis Data}

Uji prasyaratan digunakan sebagai penentu terhadap analisis data yang digunakan untuk pengujian hipotesis. Uji prasyaratan dalam penelitian ini dua macam yaitu uji linieritas dan uji normalitas, ini diujikan sebelum melakukan uji hipotesis dan untuk menentukan analisis yang akan di lakukan selanjutnya atau penentuan teknik analisis apakah paramatis atau non parametis.

\section{a. Uji Linieritas}

Dengan menggunakan tabel ANOVA pada SPSS, akan dilihat nilai Sig.linearity \& Sig.deviation from linearity dari setiap variabel bebas dengan variabel terikat dibandingkan dengan tingkat signifikan $(\alpha-0,05)$ Nilai Sig.linearity menunjukkan sejauh mana variabel bebas berbanding tepat digaris lurus. Apabila nilai Sig.linearity lebih kecil dari tingkat signifikansi $(\alpha-0,05)$, maka 
regresi linier dapat dipergunakan untuk menjelaskan pengaruh antara variabel-variabel yang ada. Sedangkan nilai Sig.deviation from linearity menunjukkan selinier apa data yang dipergunakan. Apabila nilai Sig.deviation from linearity lebih besar dari tingkat signifikan $(\alpha-0,05)$, maka regresi linier dapat dipergunakan untuk menjelaskan pengaruh antara variabel-variabel yang ada.

Tabel 7.

Data Hasil Uji Linieritas

\begin{tabular}{|l|c|c|}
\hline \multicolumn{1}{|c|}{ Variabel } & F & Sig \\
\hline $\begin{array}{l}\text { Pembelajaran kewirausahaan dengan } \\
\text { Keterampilan wirausaha }\end{array}$ & 0,681 & 0,721 \\
\hline $\begin{array}{l}\text { Pembelajaran kewirusahaan dengan } \\
\text { minat wirausahaa }\end{array}$ & 1,997 & 0,170 \\
\hline
\end{tabular}

Sumber:Lampiran 8

Kriteria pengujian linieritas adalah jika harga Fhitung lebih besar dari pada Ftabel atau jika nilai Sig $>0,05$, maka hubungan antara variabel bebas dan variabel terikat adalah linear. Data untuk pembelajaran kewirausahaandengan terhadap keterampilan siswa, dari hasil analisa dapat diketahui bahwa harga F sebesar 0,681 dengan nilai Sig 0,721 (lebih besar dari 0,05 ). Sedangkan data untuk pembelajaran kewirausahaan terhadap minat wirausaha, dari hasil analisa dapat diketahui bahwa harga $\mathrm{F}$ besar 1,997 dengan nilai Sig 0,170. (lebih besar dari 0,05). Oleh karena nilai Sig lebih besar dari 0,05 maka dapat disimpulkan antara variabel bebas dengan variabel terikat terdapat hubungan yang linier.

\section{b. Uji Normalitas}

Uji Normalitas yang digunakan untuk mengetahui distribusi penyebaran data setiap variabel dalam penelitian ini. Uji normalitas yang digunakan dalam penelitian ini adalah menggunakan rumus chi kuadrat $\left(\chi^{2}\right)$. Perhitungannya menggunakan bantuan komputer dengan program aplikasi Statistical Product and Service Solution (SPSS versi 16.0 for Windows).

Tabel 8.

Uji Normalitas Pembelajaran Kewirausahaan, Keterampilan Dan Minat Wirausahaa

\begin{tabular}{|c|c|c|c|}
\hline & $\begin{array}{c}\text { Variabel Pembelajaran } \\
\text { Kewirausahaan }\end{array}$ & $\begin{array}{c}\text { Variabel } \\
\text { Keterampilan } \\
\end{array}$ & $\begin{array}{l}\text { Variabel } \\
\text { Minat }\end{array}$ \\
\hline $\begin{array}{l}\text { Kolmogorov } \\
\text {-Smirnov Z }\end{array}$ & 0.574 & 0.843 & 0.563 \\
\hline $\begin{array}{l}\text { Asymp. Sig. } \\
\text { (2-tailed) }\end{array}$ & 0.897 & 0.476 & 0.909 \\
\hline
\end{tabular}


Sumber: Lampiran 9.

Berdasarkan Tabel 4.11 bahwa variable pembelajaran kewirausahaan memiliki nilai K-S sebesar 0.574 dengan AsyimpSig sebesar 0.897. Maka dapat disimpulkan bahwa data berdistribusi normal mengingat Asyimp-Sig lebih besar dari 0.05. Untuk variabel keterampilan memiliki nilai K-S sebesar 0.843 dengan Asyimp-Sig sebesar 0.476. Maka dapat disimpulkan bahwa data berdistribusi normal mengingat Asyimp-Sig lebih besar dari 0.05. Untuk variabel minat memiliki nilai K-S sebesar 0.563 dengan Asyimp-Sig sebesar 0.909. Maka dapat disimpulkan bahwa data berdistribusi normal mengingat Asyimp-Sig lebih besar dari 0.05 .

\section{Uji Hipotesis}

\section{a. Uji Statistik Individual (Uji t)}

Tabel 9.

Uji hipotesis one table

test

\begin{tabular}{|l|l|l|}
\hline Variabel & T & Sig. \\
\hline $\begin{array}{l}\text { Pembelajaran Kewirausahaan } \\
(\mathrm{X})\end{array}$ & 37,00 & 0,00 \\
\hline Keterampilan Wirausaha (Y1) & 34,33 & 0,00 \\
\hline Minat Wirausaha (Y2) & 33,56 & 0,00 \\
\hline
\end{tabular}

Sumber: Lampiran 10

\section{1) Uji hipotesis pertama (keterampilan kewirausahaan)}

Pengujian hipotesis dengan menggunakan pengolahan SPSS

yaitu apabila t hitung $>\mathrm{t}$ tabel atau hasil nilai signifikasi $<$ dari 0,05 maka Ha diterima dan Ho ditolak, Sebaliknya apabila $t$

hitung $<$ t tabel atau hasil nilai signifikasi > dari 0,05 maka Ho diterima dan Ha ditolak. Kriteria pengujian taraf uji signifikansi $\alpha$

untuk uji dua pihak 0,05. Dengan d.b= N

Hasil uji $\mathrm{t}$ dapat dilihat dari One-sample test yaitu: pengujian variabel pembelajaran kewirausahaan (X) terhadap Keterampilan wirausaha, dari hasil perhitungan t hitung 34,33 $>2,086$ atau sig $(0,00<0,05$. Dengan demikian $\mathrm{Ha}$ diterima dan Ho titolak.

\section{2) Uji hipotesis kedua (minat kewirausahaan)}

Pengujian hipotesis dengan menggunakan pengolahan SPSS yaitu apabila $t$ hitung $>t$ tabel atau hasil nilai signifikasi < dari 0,05 maka Ha diterima dan Ho ditolak, Sebaliknya apabila t hitung $<\mathrm{t}$ tabel atau hasil nilai signifikasi $>$ dari 0,05 maka Ho diterima dan Ha ditolak. Kriteria pengujian taraf uji signifikansi $\alpha$ untuk uji dua pihak 0,05. Dengan d.b $=20$.

Hasil uji $\mathrm{t}$ dapat dilihat dari One-sample test yaitu: pengujian variabel pembelajaran kewirausahaan $(X)$ terhadap 
Minat Wirausaha (Y2), dari hasil perhitungan t hitung 33,56 >

2,086 atau sig $(0,00<0,05$. Dengan demikian $\mathrm{Ha}$ diterima dan Ho titolak.

Pembelajaran kewirausahaan merupakan usaha yang dilakukan lembaga pendidikan untuk mananamkan pengetahuan, nilai, jiwa, dan sikap kewirausahaan kepada peserta didik guna membekali diri menjadi manusia yang mandiri, kreatif, dan inovatif.Hal ini bertujuan untuk menciptakan wirausahawirausaha baru yang handal dan berkarakter. Pembelajaran kewirausahaan inilah yang akan menentukan keterampilan siswa untuk meningkatkan keterampilan dalam wirausaha dan berani mengambil resiko, karena di dalam pelatihan pendidikan kewirausahaan siswa diajarkan untuk bekerja dengan kemampuan sendiri dan bimbingan sehingga akan mandiri. Dalam hal ini pembelajaran kewirausahaan mempengaruhi keterampilan dan minatwirausaha siswa.

Dari hasil pengolahan data secara deskriptif maka diperoleh jawaban responden variabel pembelajaran kewirausahaan terhadap keterampilan wirausaha siswa dengan total skor terendah sebesar 21 dan skor tertinggi sebesar 44. Dari hasil yang diperoleh dengan persentase 5\% siswa memiliki skor rendah dan $40 \%$ siswa memiliki jawaban tinggi. Kemudian selanjutnya responden atau siswa memiliki anggapan yang berbeda-beda mengenai pembelajaran kewirausahaan terhadap keterampilan wirausaha berdasarkan angket yang telah disebarkan yaitu 35,5\% siswa memiliki pandangan tentang keterampilan wirausaha dalam kategori kurang baik, 60\% siswa memiliki pandangan dalam kategori baik dan 5\% siswa memiliki pandangan dalam kategori sangat baik.

Untuk variabel minat wirausaha siswa dengan total skor terendah sebesar 24 dan skor tertinggi sebesar 43. Dari hasil yang diperoleh dengan persentase 5\% siswa memiliki skor rendah dan $55 \%$ siswa memiliki jawaban tinggi. Kemudian selanjutnya responden atau siswa memiliki anggapan yang berbeda-beda mengenai pembelajaran kewirausahaan terhadap keterampilan wirausaha berdasarkan angket yang telah disebarkan yaitu 30\% siswa memiliki pandangan tentang keterampilan wirausaha dalam kategori kurang baik, 65\% siswa memiliki pandangan dalam kategori baik dan 5\% siswa memiliki pandangan dalam kategori sangat baik.

Selanjutnya data-data penyebaran angket dilakukan pengujian prasyarat analisis.Adapun pengujian prasyarat analisis yang dilakukan adalah uji linieritas dan uji normalitas.jika harga Fhitung lebih besar dari padaFtabel atau jika nilai Sig>0,05, maka hubungan antara variabel bebas dan variabel terikat adalah linear. Pada pengujian uji linieritas data untuk keterampilan dan minat wirausaha siswa didapatkan hasil yaitu dari hasil analisa dapat diketahui bahwa harga F=0,681dengan nilai $\mathrm{Sig}=0,721>0,05$; dan F 1,997 dengan nilai Sig $=0,170>0,05$. Oleh karena nilai Sig $>0,05$ maka dapat disimpulkan antara variabel bebas dengan variabel terikat terdapat hubungan yang linier. 
Pada pengujian uji normalitas data dilakukan untuk menguji apakah data dalam variabel-variabel yang diteliti berdistribusi normal atau tidak.Adapun hasil uji prasyarat yang dilakukan oleh peneliti membuktikan bahwa data pembelajaran kewirausahaan berdistribusi normal. Apabila harga chi kuadrat pada perhitungan $\left(\chi^{2}\right.$ hitung) taraf sifnifikasi $5 \%<$ chi kuadrat tabel maka distribusi datanya normal. Sebaliknya apabila harga chi kuadrat dengan taraf sifnifikasi $5 \%$ pada hasil perhitungan ( $\chi^{2}$ hitung) >chi kuadrat tabel maka distribusi datanya tidak normal. Dari hasil analisa dengan menggunakan program SPSS didapatkan hasil yaitu: variabel pembelajaran kewirausahaan X2 hitung $=0,897<$ chi kuadrat $5 \%=31,410$; variabel keterampilan wirausaha $\mathrm{X} 2$ hitung $=0,576<$ chi kuadrat $5 \%=31,410$; dan variabel minat wirausaha X2 hitung $=0,909<$ chi kuadrat $5 \%=31,410$. Dari hasil perhitungan dapat dimpulkan bahwa ketiga variabel tersebut terdistribusi normal.

Uji hipotesis selanjutnya membuktikan bahwa variabelpembelajaran kewirausahaan memiliki pengaruh yang signifikan antara terhadap keterampilan wirausaha siswa, hal ini dibuktikan dari uji hipotesis diperoleh thitung 34,33>2,086 atau sig $(0,00<0,05$. Sedangkan untuk variabel pembelajaran memiliki pengaruh yang signifikan terhadap minat wirausaha dibuktikan dari hasil pengujian hipotesis yaitu t hitung 33,56>2,086 atau sig $(0,00<0,05$. Dengan demikian $\mathrm{Ha}$ diterima dan Ho titolak dengan $\mathrm{dk}=\mathrm{n}=20(2,086)$.

Dimana pembahasan mengenai pembelajaran kwirausahaan merupakan pembelajaran yang mengajarkan penanaman nilainilai kewirausahaan yang akan membentuk karakter dan perilaku untuk berwirausaha agar peserta didik dapat mandiri. Pembelajaran kewirausahaan juga mampu membekali peserta didik dengan berbagai kompetensi yang nantinya akan membawa manfaat besar bagi kehidupannya.

Pembelajaran kewirausahaan yang dilakukan dalam dunia pendidikan SMK dalam jurusan yang telah ditentukan sehingga menghasilkan beberapa peserta didik yang mempunyai kecerdasan,keterampilan atau kemampuan setempat dalam bidang wirausaha, sehingga menghasilkan para peserta didik yang mempunyai keterampilan dan minat dalam wirausaha untuk membantu perekonomian negara dan membuka lapangan pekerjaan yang bisa membantu perekonomian masyarakat menengah.

Variabel X untuk Y1 dan Y2 menyatakan bahwa pembelajaran kewirausahaan berpengaruh terhadap keterampilan dan minat wirausaha siswa, hal ini dibuktikan dengan uji hipotesis menggunakan uji t. Dimana pada uji t,karena signifikansi lebih besar dari batas kesalahan, hal ini berarti bahwa kontribusi variabelpeembelajaran kewirausahaan berpengaruh signifikan terhadap keterampilan dan minat wirausaha pada siswa XI Jurusan Jasa boga SMK NW Pancor Tahun 2016/2017.

Hal ini dibuktikan dengan hasil penelitian hipotesis "Ada pengaruh yang signifikan terhadap pembelajaran kewirausahaan 
yang mempengaruhi keterampilan dan minat wirausahaa siswa kelas XI jurusan jasa boga di SMK NW Pancor Tahun 2016/2017"diterima.

\section{KESIMPULAN}

Berdasarkan hasil penelitian dan pembahasan didapat hasil sebagai berikut :

1. Ada pengaruh yang signifikan antara pembelajaran kewirausahaan dengan keterampilan wirausaha siswa kelas XI jurusan jasa boga SMK NW Pancor tahun 2016/2017, hal ini ditunjukkan dengan diperoleh thitung $>$ ttabel yaitu 34,33 $>2,086$ atau sig 0,00 $<0,05$ dengan $\mathrm{dk}=2=$ $(2,086)$. Dengan demikian $\mathrm{H}_{\mathrm{a}}$ diterima dan Ho titolak, hal ini menunjukkan bahwa pembelajaran kewirausahaan lebih dominan mempengaruhi keterampilan siswa, sehingga semakin besar pengaruh pembelajaran kewirausahaan maka semakin besar pula keterampilan wirausaha siswa.

2. Ada pengaruh yang signifikan antara pembelajaran kewirausahaan dengan minat wirausaha siswa kelas XI Jasa Boga SMK NW Pancor Tahun 2016/2017, hal ini ditunjukkan dengan thitung 33,56 > 2,086 atau sig $\left(0,00<0,05\right.$ dengan $\mathrm{dk}=20(2,086)$. Dengan demikian $\mathrm{H}_{\mathrm{a}}$ diterima dan Ho titolak.

\section{DAFTAR PUSTAKA}

Abror, Rachman. 1993. Psikologi pendidikan. Yogyakarta: PT Tiara Wacana.

Akbar, Sa'dun. 2007. Pembelajaran Nilai Kewirausahaan dalam Perspektif

Pendidikan Umum (Prinsip-prinsip dan Faktor-faktor Percepatan Proses Internalisasi Nilai Kewirausahaan). Malang: Universitas Negeri Malang.

Anggraini \& Sukardi. 2015. Pengembangan Modul Prakarya dan Kewirausahaan Materi Pengolahan Berbasis Product Oriented Bagi Peserta Didik SMK. Jurnal Pendidikan Vokasi.

Anwar. 2012. Pendidikan kecakapan hidup (life skill education.

Arikunto, Suharsimi. 2010. Prosedur penelitian suatu pendekatan praktik. Jakarta: PT Rineka Cipta

Asmani, Jamal Ma'mur. 2011. Sekolah Enterpreneur. Yogyakarta: Harmoni. Astiti, Yunita Widyaning. 2014. Pengaruh Pendidikan Kewirausahaan

Terhadap Motivasi Berwirausaha dan Keterampilan Berwirausaha Mahasiswa Pendidikan Ekonomi Universitas Negeri Yogyakarta. Yoyakarta: Universitas Yogyakarta.

Agus, Widarjono. 2010. Analisis stastika Multivariat Terapan.

Yogyakarta:

UPP STIM YKPN.

Basrowi. 2011. Kewirausahaan Untuk Perguruan Tinggi. Bogor: Ghalia Indonesia.

Buchari, Alma. 2011. Kewirausahaan. Bandung: Alfabeta 2004. Kewirausahaan. Bandung: Alfabeta 
Dewi, Anita Volintia. 2013. Pengaruh Pengalaman Kewirausahaan dan Keterampilan Kejuruan Terhadap Motivasi Berwirausaha Siswa. Jurnal. Universitas Negeri Yogyakarta

Sukardi. 1998. PendidikanKonseling dalam Bimbingan Karir. Jakarta:

Ghalia Indonesia

Fitriani \& Aprilia. 2012. Faktor-Faktor Yang Mempengaruhi Minat Berwirausaha Pada Siswa Kelas XII SMK Negeri 1 Kandeman Kabupaten Batang. Economic Education Analysis Journal, 1 (2): 1-5

Ghozali, Imam. 2006. Aplikasi Analisis Multivariate dengan Program SPSS. Semarang: Universitas diponegoro

Kamil, Mustofa. 2010. Model Pendidikan Dan Pembelajaran (Konsep Dan Aplikasi). Bandung: Afabeta

Kasmir. 2012. Kewirausahaan. Jakarta: Rajawali Pers

Mulyasa. 2006. Kurikulum berbasis kompetensi, konsep karakteristik, dan implementasi. Bandung. PT Remaja Rosdakarya

Rownland. 2012. Analisis Data. rowlandpasaribu.files.wordpress.com/.

Suryana. 2006. Kewirausahaan Edisi 3. Jakarta: Salemba Empat.

Sugiyono. 2008. Metode penelitian kuantitatif kualitatif dan $R \quad \& \quad D$. Bandung: Alfabeta.

Sugiyono. 2010. Metode penelitian pendidikan (pendekatan kuantitatif, kualitatif dan R\&D). Badung: Alfabeta.

Yulianti, Ida. 2013. Pengaruh mata pelajaran Kewirausahaan dan Motivasi Siswa terhadap Minat Berwirausaha Siswa Kelas XI Di SMK Muhammadiyah Salaman Kabupaten Magelang. Jurnal. Universitas Muhammadiyah Purworejo.

Wahyono, Budi. 2013. Pengaruh Pendidikan Kewirausahaan Terhadap Niat Berwirausaha Siswa SMK N 1 Pedan Tahun 2013. Tesis. Universitas Sebelas Maret Surakarta.

Wibowo, Agus. 2011. Pendidikan Kewirausahaan (Konsep Dan Strategi). Yogyakarta: Pustaka Pelajar 